\title{
Study on Course's Practice Teaching Standardized Construction in University
}

\author{
YAN Huihui \\ Marxism Department, Shandong University at Weihai, China 264209 \\ E-mail:yanhh.ok@163.com
}

Keywords: practice teaching,practice base,University student

\begin{abstract}
Traditional teaching mode generally is based on classroom teaching,teaching is generally implemented step by step in accordance with the teaching materials. Teachers should establish a student "oriented" concept,impose on students more humane care,change the "indoctrination" approach with democracy grooming style approach replaced.Teachers' teaching content should do with the times,enrich the teaching,to grasp the pulse of the times,the era of new issues raised by the answer.This table give some solutions:conbine thematic teaching and chapters teaching;enhance students' practical teaching effectiveness;strength the construction of practice base.
\end{abstract}

\section{Introduction}

Traditional teaching mode generally based on classroom teaching.Teaching is generally implemented step by step in accordance with the teaching materials.So traditional teaching methods' characteristics are single teaching methods v teaching process closed、teaching content securely.With the arrival of the digital age,contemporary college students have formed a series of new features:first,the computer became an important tool for students'learning. The classroom is not the only way they get knowledge and information,even no longer the main way.Network has started to become the main way for college students to acquire knowledge and information.Based on this characteristic,the traditional teaching model obviously does not meet the demands of the students, this will force teachers' teaching model to suit the characteristics of digital age.Teachers should widely used multimedia teaching methods student loved,so boring classroom lively up,attracting students;second,open character.Network society without borders meets the needs of college students' openness. Theses features also bring the impact of the traditional teaching model,teachers are no longer satisfied with the system taught in the classroom,but to practise into teaching;third,the strong interaction of information exchanged.In the digital age,students haven't passive recipients of information, they will take the initiative to choose,dissemination, and even production information.

The main problem of current teaching is that teachers contradiction "dominant" role and students "subject" status.Since ancient times,the dominant position of teachers in the teaching process is the "iron law".However,with the development of modern education,there is a growing emphasis on students' dominant position in education.Indeed,the simple teacher-led is obviously wrong.However,giving up the leading role of the teacher,one-sided emphasis on the dominant position of students, resulting in the teaching process drift,these are not desirable.The current situation is that some students are keen to "simply" to participate in the teaching process,the result is that is difficult to ensure the completion of the normal teaching tasks. So,teachers should establish a student "oriented" concept,impose on students more humane care;change the "indoctrination" approach with democracy grooming style approach replaced;do with the times on teaching content,giving promptly innovations to enrich the teaching,to grasp the pulse of the times,the era of new issues raised by the answer.

\section{Combine thematic teaching and chapters teaching}

In the limited time available,if teaching content is required exhaustive,that will make that some issues are not bound to make deep,so educational reform is a big trend. When the class are no longer 
increased,solution to the problem is to enhance the effectiveness of teaching theory in the limited class.

Thematic teaching is main,the thematic teaching and chapters teaching combined together.Chapter teaching's drawbacks are:content updates can not keep pace with changes in the practice and theory of development,social reality and students practical is not linked,the lack of contemporary and attraction;textbooks in some sections of the set is not ideal.The solution is to understand and become familiar with the materials, then tease out the key and difficult courses,integrate the teaching materials into a number of topics related to the topic.Current teaching materials are mainly concentrated on teaching content and teaching ideas.Textbook system may not be teaching system.Project-based teaching is exploring options to expand the teaching content and construct one of the effective measures for the teaching system.

Thematic teaching

advantages:

First,it is to help implement concise principles and to put limited time of the core teaching on key issues.Specific approach is using less time to introduce the course content system as a whole to the students,students have an overall grasp of the content and to formactual thematic focus in detail to explain concepts and ideas,so that students can really grasp the essence of the theory in a limited class.

Second,it is helpful for keeping the hot issues;lectures teaching is more attractive to students.Topic designed should be considered three aspects:focus,overcoming difficulties,select the basic system.

Finally,teachers designed the every lesson well and can catch up the progress.

\section{Enhance students' practical teaching effectiveness}

In order to improve teaching effectiveness of the practice,students should be encouraged to take the stage and give speech,as the following:

\section{1 topic set}

First,teachers prepare a dozen propositions combine content,students can choose at the beginning of the semester.The advantages of this approach are:student's lecture content can be managed by teachers,and combined with teaching content tightly.The disadvantages are:speech time is uncontrollable,some students choose more topics and will take up a lot of teachers' time.Some topics are elected less,teachers need to temporarily adjust their teaching schedules;second,topics chosed by teachers and students combined;third,teachers fully allow students to self-selected topic,the students were fully mobilized the enthusiasm. The disadvantage is greater likelihood of tricky question indeed. So in terms of student speech,topics selected need to be further refined.

\section{2 practice organization, hosting,and ratings}

Students can be divided into groups,learning committee member,monitor,competitive person form a fixed jury to keep the consistent standard of score,then teachers comment and guide.On the basis of respect for the students' score,the teacher retains the right to fine-tune the assessment of students' cores.

\section{4 strengthen the construction of practice base}

\section{1 develop the social practice base for educational programs}

For practical education more standardized,improving the quality of education,the preparation of a long-term viable teaching program is necessary.Education programs should reflect the spirit of"China Education Reform and Development Program",be clear to guide ideology and helping practice of education goals to be achieved.Teachers should make sure of social practice base before semester according to the principle of universality and particularity combined.Making time (hours)、 content and means are sure,teachers have a "chapter" to follow,organize and manage,changing the current randomness of social practice.

4.2 Social practices should be possible to be combined with student's profession.

During practice base construction,students' professional features should be considered,this is a inevitable requirement of social practice effectiveness(note:this is not in contradiction with the 
prominent features).Firms have the objective requirements for students, hope relevent professional students visiting 、 learning and propagandizing their firms.Firms hope the students can work for the firm after graduation.

\subsection{Establish social practice and scientific evaluation system}

Social practice time is very short,but the impact on students is profound.Writing social practice report is an important part of social practice. This is not only to improve the educational activities,but to enable students to think through the summary to achieve deeper understanding,and thus stimulating the students a better understanding of the community,understanding the country.

Establishing a scientific evaluation system of social practice is an important basic work:(1) requiring the provisions of the students' social practice requirements(cover,content,fonts, etc);(2)requairing a specified number of social practice reports of each class;(3)devising excellent selection conditions and selection proportion of the social practice report;(4)outstanding social practice set can be published as a internal report by the students(the first school year),awarding students enrolled certificates.

\section{4 establish special funds and gradually diversified investment mechanism to improve social practice base}

Social practice base is needed of special funds invested.It includes lecture fees of related base's person,the entrance fee,small coordination office meeting costs,class lecture fee of base's leader,base's promotional fees,students appraised award costs,and so on.

\section{5 establish school and social practice base for win-win cooperation mechanism}

Establish mechanisms of school and social practice base of win-win cooperation is the fundamental guarantee of social practice and education for sustainable development,including the contents of the following main areas:(1)monthes before the start of semester,the number v profession 、 date and leading teacher of students are submitted to the practice base in order to jointly negotiate in time;(2)fully consider all of the students' requirements(number, batch,time, etc.) of social practice base;(3)students's number participating in social practice base can not be too big,this can get poor practice effection and firms can not afford wealthy burden(selective programs to reduce batch program);(4)establish promotional pages of social practice base,strengthen outreach social work practice activities;(5)establish a mechanism of regular meetings during term leadership of the school-leaders of social practice base related and communicate information.

\section{References}

[1] Zhuang Shuchun:Construction of long-term mechanism of practice teaching in University,Party building and ideological education,2010(4),50-51

[2] Wu Jiangmei,Zhaoyu:Adaption education:important growing point of ideological and political theory course teaching practice,Thought education,2013(4):59-61

[3] Chen Zaisheng:Using of the Thoughts of self-study on Political Course Teaching,Ideological and theoretical teaching,2008(12):86-88

[4] Information on http://ysx.gzccc.edu.cn/jiaoxueguanli/jiaoxueguanlizhidu/2011-06-03/711.html

[5] Information on http://www.moe.gov.cn/publicfiles/business/htmlfiles/moe/A08_sjhj/201305

(This paper is the outcome of the Shandong University's project "Research on Practical Teaching on Marxist theory" ) 